\title{
Metastatic endobronchial hypernephroma nine-and-a-half years after nephrectomy
}

\author{
M. ANEES KHAN \\ M.D.
}

Mauricio J. Dulfano

M.D.

\section{Pulmonary Disease Section, Department of Medicine, Veterans Administration Hospital, Brooklyn, N.Y.}

\begin{abstract}
Summary
A patient with an endobronchial nodular lesion, proved to be clear cell carcinoma (hypernephroma) by fibrebronchoscopic biopsy, is described in which the primary tumour had been resected $9 \frac{1}{2}$ years before the onset of the present illness. At post-mortem the remaining kidney was found to be normal.

\section{Introduction}

Although metastatic disease of the lungs from extrathoracic tumours is a frequent occurrence (Willis, 1952), involvement of major airways is rare. Carcinoma of the kidney is the extrathoracic tumour most commonly associated with metastatic involvement of the major airways (Braman and Whitcomb, 1975). The presenting symptoms and X-ray picture may be identical with those of bronchogenic car-. cinoma. In the majority of cases, clinical manifestations of primary tumour antedate those of bronchial metastasis. If the tumour fails to recur within 5 years of removal of the primary lesion, the term 'cure' seems justified. Occasionally, however, endobronchial spread may manifest itself after a much longer interval. This tends to make primary bronchogenic carcinoma appear a more likely possibility. This communication describes such a case in which endobronchial disease appeared $9 \frac{1}{2}$ years after removal of the primary tumour.
\end{abstract}

\section{Case report}

A 70-year-old white male was admitted to the Brooklyn V.A. Hospital in 1972, with progressive exertional dyspnoea and cough productive of bloodtinged sputum of 4 months' duration. During early 1963, the patient had undergone left nephrectomy for hypernephroma and transurethral resection of transitional cell carcinoma (grade II) of the urinary bladder. Physical examination during his present admission showed evidence of congestive cardiac failure. Except for a mild degree of hepatomegaly (13 $\mathrm{cm}$ span) no abdominal mass was palpable.

Reprint requests: Dr $M$. Anees Khan, Boston City Hospital, 818 Harrison Avenue, Boston, Massachusetts 02118, U.S.A.

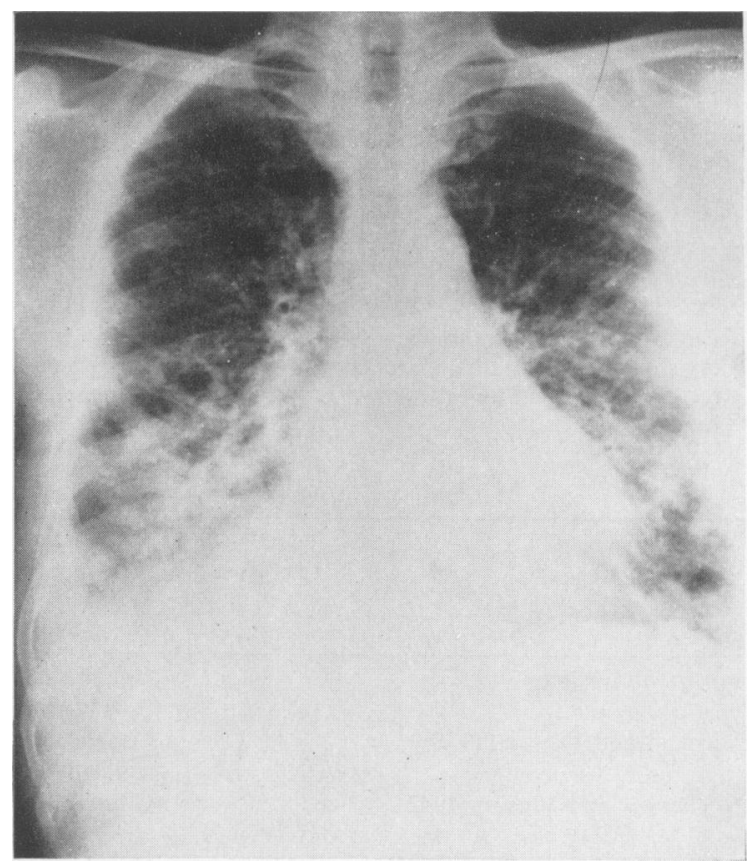

Fig. 1. Postero-anterior X-ray of the chest on admission showing multiple nodular densities (predominantly over the right lower lung field) with blunting of the right costophrenic angle.

Serum chemistries were unremarkable except for a urea nitrogen level of $68 \mathrm{mg} / 100 \mathrm{ml}$ and creatinine of $3.6 \mathrm{mg} / 100 \mathrm{ml}$. Urinalysis was unremarkable. Sputum, although grossly bloody, failed to reveal any tumour cells; acid-fast stains were negative. A chest X-ray in postero-anterior projection (Fig. 1) showed small nodular densities over the right lower lung field; these lesions did not show on lateral views. Bronchoscopic examination with flexible fibreoptic instrument disclosed blood-streaked secretions exuding from the middle lobe bronchus, and a $4 \mathrm{~mm}$ red friable nodule partially occluding the lateral segmental division (Fig. 2). Biopsy of this nodule revealed renal cell carcinoma. 


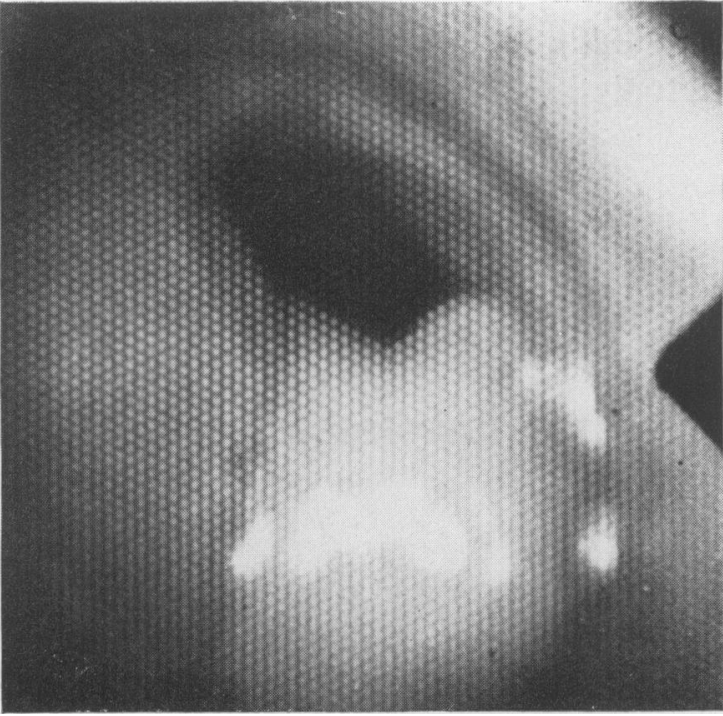

FIG. 2. Bronchoscopic view of the lateral segmental division of the middle lobe bronchus $\left(B^{4}\right)$ showing a tongue-shaped nodular lesion. Histological diagnosis: hypernephroma.
The hospital course was complicated by the development of an acute myocardial infarction, followed by rapid dissemination of the tumour. The patient died six months after admission to hospital. Post-mortem showed metastatic renal cell carcinoma involving the myocardium, both lungs (including right middle lobe bronchus), and pancreas as well as hilar and para-aortic lymph nodes. The remaining kidney was devoid of any tumour.

\section{Discussion}

The incidence of metastatic disease of the major airways has been variously reported (Braman and Whitcomb, 1975; King and Castleman, 1943: Rosenblatt, Lisa and Trinidad, 1966) ranging from $2 \%$ (Braman and Whitcomb, 1975) to $50 \%$ (Rosenblatt et al., 1966). When cases with microscopic involvement of the bronchial walls are included, as in the series of Rosenblatt et al., the incidence approaches $50 \%$.

An analysis of fifteen cases of metastatic endobronchial hypernephroma reported to date is presented in Table 1. In eight cases, manifestations of the primary tumour antedated those of bronchial

TABLE 1. Summary of cases of hypernephroma with endobronchial metastases

\begin{tabular}{|c|c|c|c|}
\hline Series & Symptoms & $\begin{array}{l}\text { Time interval } \\
\text { (between discovery of } \\
\text { primary tumour and } \\
\text { endobronchial disease) }\end{array}$ & Location \\
\hline Vinson and Martin (1932) & $\begin{array}{l}\text { Cough, haemoptysis, } \\
\text { dyspnoea }\end{array}$ & 2 years & RUL† bronchus \\
\hline Maytum and Vinson (1936) & $\begin{array}{l}\text { Cough, haemoptysis, } \\
\text { dyspnoea, weakness }\end{array}$ & 2 months** & RUL* bronchus \\
\hline Norfsinger and Vinson (1942) & $\begin{array}{l}\text { Cough, unilateral } \\
\text { wheeze }\end{array}$ & 10 months** & RLL† bronchus \\
\hline Tinney and MacDonald (1945) & $\begin{array}{l}\text { Cough, haemoptysis, } \\
\text { chest pain, dyspnoea }\end{array}$ & 2 years & LUL $\ddagger$ bronchus \\
\hline $\begin{array}{l}\text { Case records of the Massachusetts General } \\
\text { Hospital \# } 33012 \text { (1947) }\end{array}$ & $\begin{array}{l}\text { Cough, haemoptysis, } \\
\text { weight-loss }\end{array}$ & 6 years & LUL $\ddagger$ bronchus \\
\hline Seiler, Clagett and MacDonald (1950) & $\begin{array}{l}\text { Cough, haemoptysis, } \\
\text { chest pain, dyspnoea }\end{array}$ & 2 years & $\begin{array}{l}\text { LUL } \ddagger \text { bronchus } \\
\text { RLL } † \text { bronchus }\end{array}$ \\
\hline Higginson (1955) & None & 7 years & RML $\mid$ bronchus \\
\hline Caplan (1959) & Haemoptysis & 4 years & Left main bronchus \\
\hline Gerle and Felson (1963) & $\begin{array}{l}\text { Cough, haemoptysis, } \\
\text { chest pain, dyspnoea }\end{array}$ & 6 months** & $\begin{array}{l}\text { Multilobar and } \\
\text { segmental }\end{array}$ \\
\hline Gerle and Felson (1963) & Chest pain & 6 weeks** & LLL $\S$ bronchus \\
\hline Gerle and Felson (1963) & $\begin{array}{l}\text { Haemoptysis, chest } \\
\text { pain }\end{array}$ & 5 years & RUL* bronchus \\
\hline Gerle and Felson (1963) & Haemoptysis, dyspnoea & 8 years & RUL* bronchus \\
\hline Silverberg, Evans and Koehler (1969) & $\begin{array}{l}\text { Haemoptysis, cough, } \\
\text { wheeze }\end{array}$ & 9 months** & LLL $\S$ bronchus \\
\hline $\begin{array}{l}\text { Case records of the Massachusetts General } \\
\text { Hospital \# 13-1972 (1972) }\end{array}$ & Haemoptysis & 3 weeks** & $\begin{array}{l}\text { LLL } \$ \text { RML } \\
\text { RLL† bronchus }\end{array}$ \\
\hline Braman and Whitcomb (1975) & Cough, dyspnoea & 5 months** & $\begin{array}{r}\text { Right main } \\
\text { bronchus }\end{array}$ \\
\hline
\end{tabular}

\footnotetext{
* RUL, right upper lobe.

$\dagger$ RLL, right lower lobe. $\ddagger$ LUL, left upper lobe

$\S$ LLL, left lower lobe.

- RML, right middle lobe.

**Endobronchial symptoms preceded the discovery of primary lesion.
} 
involvement by an interval of 2-8 years. The remaining seven cases presented with bronchial disease 3 weeks to 10 months before any evidence of primary disease could be discovered. The present case is unique in that the metastatic endobronchial disease appeared $9 \frac{1}{2}$ years after resection of the primary lesion. Because of its segmental location, the tumour could have been missed by rigid bronchoscopic examination. The diagnosis was made quickly with the flexible fibreoptic bronchoscope, and the patient was spared the inconvenience of further studies.

\section{References}

Braman, S.S. \& WhitcomB, M.E. (1975) Endobronchial metastasis. Archives of Internal Medicine, 135, 543.

CAPlaN, H. (1959) Solitary endobronchial metastasis from carcinoma of kidney. British Journal of Surgery, 46, 624.

Case Records of the Massachusetts General Hospital (1947) Case \#33012, New England Journal of Medicine, 236, 38.

Case Records of the Massachusetts General Hospital (1972) Case \#13-1972, New England Journal of Medicine, 286, 713 .

Gerle, R. \& Felson, B. (1963) Metastatic endobronchial hypernephroma. Diseases of the Chest, 44, 225.
Higginson, J.F. (1955) A study of excised pulmonary metastatic malignancies. American Journal of Surgery, 90, 241.

King, D.S. \& Castleman, B. (1943) Bronchial involvement in metastatic pulmonary malignancy. Journal of Thoracic Surgery, 12, 305.

Maytum, C.K. \& Vinson, P.P. (1936) Pulmonary metastasis from hypernephroma with ulceration into a bronchus simulating primary bronchial carcinoma. Archives of Otolaryngology, 23, 101.

NoRfsingeR, C.D. \& VINSON, P.P. (1942) Intrabronchial metastasis of hypernephroma simulating primary bronchial carcinoma. Journal of the American Medical Association, 119, 944.

Rosenblatt, M.B., LiSA, J.R. \& Trinidad, S. (1966) Pitfalls in the clinical and histologic diagnosis of bronchogenic carcinoma. Diseases of the Chest, 49, 396.

Seiler, H.H., Clagett, D.T. \& MCDonald, J.R. (1950) Pulmonary resection for metastatic malignant lesions. Journal of Thoracic Surgery, 19, 655.

Silverberg, S.G., Evans, R.H. \& Koehler, A.L. (1969) Clinical and pathologic features of initial metastatic presentations of renal cell carcinoma. Cancer, 23, 1126.

Tinney, W.S. \& McDonald, J.R. (1945) Pulmonary metastasis of carcinoma diagnosed by bronchosocopy. Minnesota Medicine, $28,554$.

Vinson, P.P. \& Martin, W.J. (1932) Pulmonary metastasis from hypernephroma diagnosed by bronchoscopy. Archives of Otolaryngology, 15, 368.

WILlis, R.A. (1952) The Spread of Tumours in the Human Body, p. 172. Butterworth, London.

\title{
Nephrotic syndrome, sickle-cell disease and pregnancy
}

\author{
Alan M. SMith \\ M.A., B.M., B.Ch., M.R.C.P., F.R.C.S.(Fd.), F.R.C.O.G. \\ New Cross Hospital, Wolverhampton
}

\begin{abstract}
Summary
A young West Indian with sickle-cell disease and the nephrotic syndrome in the last trimester of pregnancy was treated after admission to hospital with folic acid and blood transfusion. Labour was induced by intravenous prostaglandin $E_{2}$ but the fetus died. The nephrotic syndrome resolved but the proteinuria, the cause of which it is suggested is a true sickle-cell nephropathy, persisted.
\end{abstract}

\section{Introduction}

Individuals with a sickle-cell disease may now survive well into adult life because infection is no longer a common cause of early death and crises are more effectively treated (Huntsman and Lehmann, 1974). As the life-span becomes longer, renal complications are more frequently recognized. One of these is the nephrotic syndrome, which may be the result of a specific glomerulonephritis (Miller et al., 1964; Walker et al., 1971). Pregnancy complicated by sickle-cell anaemia is uncommon (Buckle, 1968; Beacham and Beacham, 1950; Hendrickse et al., 1972), and the added complication of the nephrotic syndrome is rare.

\section{Case report}

An unmarried 21-year-old West Indian, known to have homozygous sickle-cell disease, was admitted as an emergency with suspected pre-eclampsia in the thirty-second week of her second pregnancy. When 17 years old, she had aborted spontaneously after 7 weeks of amenorrhoea. There was no record of the blood pressure nor of urinalysis before pregnancy.

The patient, $158 \mathrm{~cm}$ tall, was of slight build and 